\title{
Improving Reading Comprehension Ability Trough Mini Book Media
}

\author{
Mohamad Qomarudin Yahya $^{1}$, Kuntoro $^{2}$, Nofita Sari ${ }^{3}$, Mugi Rahayu ${ }^{4}$ \\ \{ mqyahya1972@gmail.com ${ }^{1}$, kuntorosutaryo@gmail.com ${ }^{2}$, nofitasari1179@gmail.com ${ }^{3}$, \\ mugirahayu185@gmail.com ${ }^{4}$ \} \\ ${ }^{1}$ SDN 2 Mrebet Purbalingga \\ ${ }^{2}$ Universitas Muhammadiyah Purwokerto \\ ${ }^{3}$ SDN 3 Grendeng Banyumas \\ ${ }^{4}$ SDN 2 Tangkisan Purbalingga
}

\begin{abstract}
This study aims to improve students' reading skills. The research was made to see the condition of most of the students who have not been able to read, especially reading comprehension. The research subjects are fourth grade studentssemester 1 at SD Negeri 2 Mrebet for the 2020/2021 Academic Year (as many as 16 students). Data was collected by means of observation and written tests. The data obtained were analyzed descriptively qualitatively. The results of this study indicate that the use of Mini Book as a learning media can improve students' reading comprehension skills. The number of students has achieved complete learning, so that the specified target is achieved. From the results obtained, the researchers concluded that the use of Mini Book Media Can Improve Reading Comprehension Skills at SD Negeri 2 Mrebet can be improved and declared complete.
\end{abstract}

Keywords: Mini Book Media, Reading Comprehension Ability

\section{Introduction}

In the era of the industrial revolution 4.0 , Indonesian currently has great power to become a world language, an international language, the language used in international forums [1]. , towards the Era of Society 5.0 the Indonesian language used by the community is growing. Indonesian people are required to be skilled in using Indonesian properly and correctly so that they can go global. On the other hand, according to The US Foreign Institute, Indonesian is included in the category of language that is easy to learn and requires a fairly short time to learn Indonesian [2].

To overcome the problems mentioned above, the researchers used mini book media as one of the solutions. The function of learning media was viewed from two things, namely the learning process as a communication process and interaction activities between students and the environment. Judging from the learning process as a communication process, the function of the media is as a carrier of information from the source (facilitator) to the recipient ( student ). Judging from the learning process as an interaction activity between students and their environment, the function of language can be identified based on the excess of media and communication barriers that may arise in the learning process [3] 
Learning resources are defined as information that is presented and stored in various forms of media, which aims to assist students in learning as a manifestation of the curriculum [4]. For this reason, the use of media and learning resources must be in accordance with the needs of students. and packaged attractively so that students are able to take values and messages from the media they use . Mini Book is a learning media that is included in the type of print media [3]. In the Mini Book usually focus on the core and goals to be achieved. In this study, the Mini Book will contain various stories and be packaged using language that is in accordance with the thinking abilities of students [3]. The researcher chose the mini book as a media as the goal to improve reading comprehension skills in SD Negeri 2 Mrebet.

\section{Research Method}

Design method were used is Classroom Action Research. And the research is done through two cycles and each cycle is done through four phases: planning, action, observation and reflection [5]. The second cycle is carried out based on the previous cycle to improve every deficiencies that exist in previous studies. This research was conducted at SD Negeri 2 Mrebet which is located on Jalan Raya Pengalusan Mrebet, Purbalingga Regency. The research time was carried out for 4 months, with a student population is 16 students

The data collection technique used in this research is by means of observation. The instruments used to carry out this research are (1) document observing actions in the form of notes for Indonesian students to learn during learning, the final document of the cycle. (2) Another source of information is the facilitator who makes observations during the implementation of the action. (3) test sheets in the form of questions that are used to see the mastery of letters in the mini book media about reading comprehension that has been taught. [5]

The data obtained were analyzed and described in accordance with the existing problems. The interactive learning design and assignment of work were validated by the facilitator. Student learning observation data were analyzed using simple descriptive analysis by calculating the percentage increase in students' motivation in teaching and learning activities in the classroom. [6]

\section{Results and Discussion}

\subsection{Result}

The researcher makes a lesson plan to be implemented, then prepares a mini book media used in learning. In addition, a guidebook for the use of mini-book media is also prepared that will guide students in activities (work). Also create questions for student homework, assessment systems, preparation of handbooks learners, preparation of evaluation questions, evaluation sheets. Initial learning conducted by researchers has not achieved optimal results. The results achieved are still low. Learning outcomes in the initial conditions as shown in the Table 1. 
Table 1. The initial student scores

\begin{tabular}{lcccc}
\hline \multicolumn{1}{c}{ Criteria } & $\begin{array}{c}\text { Range } \\
\text { of score }\end{array}$ & $\begin{array}{c}\text { Student } \\
\text { Numbers }\end{array}$ & Presentation & Average \\
\hline Uncompleteness & $40-70$ & 10 & $62.5 \%$ & 62 \\
Completeness & $71-100$ & 6 & $37.5 \%$ & \\
\hline
\end{tabular}

Based on Table 1, at the time of the initial learning, the researchers made improvements to the learning of a first run (first cycle). Learning to use it is done with an instructional media image and letter card in classics. The learning outcomes on $1^{\text {st }}$ Cycle can be seen at Table 2.

Table 2. The first cycle student scores

\begin{tabular}{lcccl}
\hline \multicolumn{1}{c}{ Criteria } & $\begin{array}{c}\text { Range } \\
\text { of score }\end{array}$ & $\begin{array}{c}\text { Student } \\
\text { Numbers }\end{array}$ & Presentation & Average \\
\hline Uncompleteness & $40-70$ & 4 & $25 \%$ & 75 \\
Completeness & $71-100$ & 12 & $75 \%$ & \\
\hline
\end{tabular}

Based on the Table 2, there is an increase to learning outcomes. However, these improvements have not reached the desired target. Therefore, it is still necessary to improve further learning through cycle II. Cycle II learning is done by using mini book media.

Table 3. The second cycle student score

\begin{tabular}{lcccc}
\hline \multicolumn{1}{c}{ Criteria } & $\begin{array}{c}\text { Range } \\
\text { of score }\end{array}$ & $\begin{array}{c}\text { Student } \\
\text { Numbers }\end{array}$ & Presentation & Average \\
\hline Uncompleteness & $40-70$ & 1 & $6.25 \%$ & 93 \\
Completeness & $71-100$ & 15 & $93.75 \%$ & \\
\hline
\end{tabular}

Based on the data above, in cycle II the average number of students has reached 77, there are only 1 children with special needs who are still not completeness. In cycle II the average student has reached $93,75 \%$, this shows that the learning process in cycle II shows a very significant increase, where mastery learning has been achieved and even exceeds the set target.

\subsection{Discussion}

Initially, the activities of the teaching and learning process for Indonesian subjects were still centered on the facilitator and less on the students. The emphasis in teaching and learning activities is on teaching rather than learning. Because of this condition, fourth-grade learning activities are typically low and teacher-centered, and very few students are skilled at reading comprehension. This is why the average learning outcomes in Indonesian pre-media reading are only 62.5 percent.

After researchers conducted a study to be a medium of learning, I began to rise with learning completeness of $75 \%$ at the end of the learning cycle tests. This means that it has not yet reached the specified completion level of 70 . As a result, researchers must continue the second cycle by improving the learning process based on the findings of the first cycle's activities. 


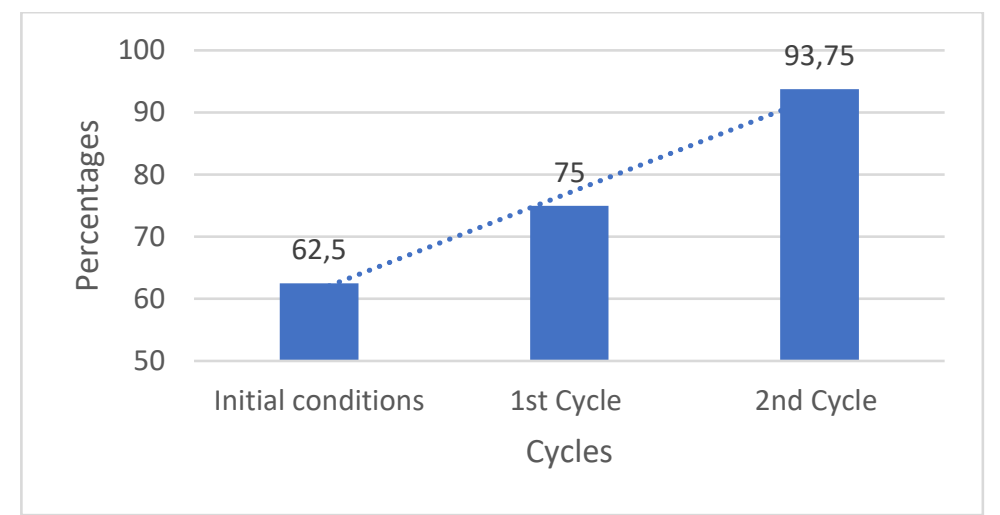

Figure 1. Student Completedness of Score

Figure 1 showed the student completedness of score on Indonesian subject. More and more students are reaching a score equal to or higher than the minimum completeness criteria in thematic learning with Indonesian content by using media mini books.

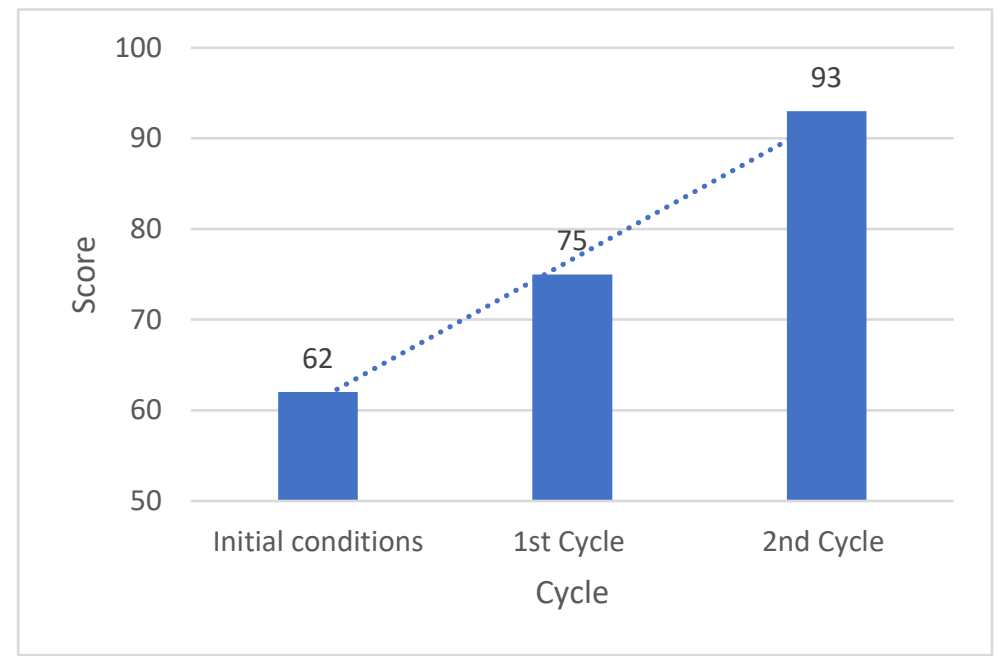

Figure 2. Student Average Score during Learning

Figure 2 showed the student average score on Indonesian subject. The figure shows an increase in student conceptual understanding. The image depicts an improvement in student understanding. Students' success- when they use mini book media.

The use of mini books is one of the media that can motivate students in class V Sonokusumo 1 Semampir District Surabaya to increase their reading and writing activities [3]. Mini books are used for a variety of reasons, including: (1) they are easily made by students, (2) the mini form makes it easy for students to fill out and fulfill them, (3) they can motivate students to produce as many mini 
books as possible, (4) students can compete in producing mini books, and (5) they give students the impression that making books is easy and fun [9]

The results of the teacher's writing are adequate. Teachers, on the other hand, should involve students in the production of expository writing when modeling. The teacher must express his thoughts based on the framework he has created. The teacher has visited the student group during the revision stage. Group visits, on the other hand, should be evenly distributed among all groups. Then allow the group to ask questions about the revised writing. The teacher does not involve students in this case; rather, the teacher mentions the material he has taught [3].

Individual students use the learning media provided by facilitator [4]. The results of the teacher's writing are adequate. Teachers, on the other hand, should involve students in the production of expository writing when modeling. The teacher must express his thoughts based on the framework he has created. The teacher has visited the student group during the revision stage. Group visits, on the other hand, should be evenly distributed among all groups. Then allow the group to ask questions about the revised writing. The teacher does not involve students in this case; rather, the teacher mentions the material he has taught.

Students are actively involved in finding answers, making predictions, and dealing with various related realities. Pointing out or mentioning specific parts of the image based on the questions / tasks available Students have used all of their experience and knowledge in such activities [7]. Children will learn more effectively if they incorporate their schemes into their learning [10-11]. A schemata is an abstract structure in a child's brain whose content is related to the material or problem that will be studied. Schemata in children can take the form of knowledge and/or experience with learning material.

\section{Conclusion}

Based on the description in the form of discussion and review of the data mentioned above, it can be concluded that the use of media mini books can improve reading comprehension in the students of fourth grade of SD Negeri 2 Mrebet the academic year 2020/2021. Through this media, they involved in finding answers, making predictions, and dealing with various related realities actively. So, they motivated to learn something.

\section{Reference}

[1] Collins JT. Bahasa Melayu bahasa dunia: Sejarah singkat. Yayasan Obor Indonesia; 2005..

[2] Nirmala SD. Kemampuan Berpikir Kritis Siswa Kelas IV Se-Gugus 2 Purwasari Dalam Membaca Pemahaman Melalui Model Fives Dan Model Guided Reading. Dinamika Jurnal Ilmiah Pendidikan Dasar. 2019 Feb 12;10(2).

[3] Sukidi M, Sukidi M, Abdullah MH. Use of the Mini Book to Improve Expositorial Writing Skills of V Class Student of SDN Wonokusumo 1 Surabaya, Indonesia. In5th International Conference on Education and Technology (ICET 2019) 2019 Dec (pp. 104-110). Atlantis Press.

[4] Falahudin I. Use of Media in Learning. Widyaiswara Circle Journal. 2014;1(4):104-17.

[5] Arikunto S. Research procedure a practical approach. Jakarta: Rineka Cipta. 2010:152. 
[6] Wati LR, Arifiandi MD, Prastiwi F. Artikel Hasil Penelitian. Journal of Issues in Midwifery. 2017 Nov;1(2):1-8.

[7] Septiani S, Kristiawan M, Fitriani Y. School Literacy Movement, Providing Solution. Education Journal. 2020;3(2):43-52.

[8] Jalil SN. Perbedaan Hasil Belajar Matematika antara Penggunaan Media Mini Book dan Big Book pada Peserta Didik Kelas VI di Madrasah Ibtidaiyah (MI) Al-Abrar Kota Makassar (Doctoral dissertation, Universitas Islam Negeri Alauddin Makassar).

[9] Nopilda L, Kristiawan M. Gerakan literasi sekolah berbasis pembelajaran multiliterasi sebuah paradigma pendidikan abad ke-21. JMKSP (Jurnal Manajemen, Kepemimpinan, dan Supervisi Pendidikan). 2018 Jul 25;3(2):216-31.

[10] Wahyuliani Y, Supriadi U, Anwar S. Efektivitas Penggunaan Media Pembelajaran Flip Book Terhadap Peningkatan Hasil Belajar Siswa Pada Mata Pelajaran PAI Dan Budi Pekerti Di SMA Negeri 4 Bandung. TARBAWY: Indonesian Journal of Islamic Education. 2016;3(1):22-36.

[11] Anzar SF, Mardhatillah M. Analisis Kesulitan Belajar Siswa Pada Pembelajaran Bahasa Indonesia di Kelas V SD Negeri 20 Meulaboh Kabupaten Aceh Barat Tahun Ajaran 2015/2016. Bina Gogik: Jurnal Ilmiah Pendidikan Guru Sekolah Dasar. 2018 May $31 ; 4(1)$. 